\title{
Building the Integrity of Legislative Members Through Low-Cost Election Process
}

\author{
Henry Indraguna ${ }^{1}$, Hartiwiningsih ${ }^{2}$, I Gusti Ayu Ketut Rachmi Handayan ${ }^{3}$ \\ ${ }^{1.2 .3}$ Universitas Sebelas Maret \\ Surakarta, Indonesia \\ hendryindraguna@student.uns.ac.id
}

\begin{abstract}
Legislative candidates currently face large costs due to direct legislative election. Therefore, only candidates with strong finances have the opportunity to nominate. The situation causes the appearance of less qualified candidates. Instead of building knowledge, ability, and integrity, candidates only focus on building their financial strength. Legislative election violations may occur due to intentional elements or due to negligence. Anyone can commit election violations. Everyone has the potential to become perpetrators of election violations. As an anticipation, Law number 7 of 2017 on General Elections has regulated the election at every stage in the form of obligations and prohibitions with additional sanctions. To date, the legal sanctions are only about removal of names from nominations. No legal action has been taken regarding this issue. On the other hand, law enforcement officers also do not understand the application of material legal rules in the field of criminal acts related to general elections.
\end{abstract}

Keywords- Legislative, Election, Election Violations, Sanctions.

\section{INTRODUCTION}

Election is a means of succession of government elites carried out in democratic countries. Genuine election is based on the principles of democratic elections: direct, general, free, secret, honest, fair, and conducted periodically.[1] Legislative candidates currently face large costs due to direct legislative election. Therefore, only candidates with strong finances have the opportunity to nominate. The situation causes the appearance of less qualified candidates. Instead of building knowledge, ability, and integrity, candidates only focus to build their financial strength.[2] The candidates think that the large amount of money they spend during the campaign period can be replaced when they are elected as members of the legislature. The idea may lead to corruption.[3]

The background of election crimes involving actors from institutions that have authority in making election decisions may occur because there are no arrangements regarding vertical or horizontal accountability. The election management institutions, the General election Comission (KPU) and the Election Supervisory Body (Bawaslu), have no authority to make decisions regarding the conduct of elections.[4]
The Law number 7 of 2017 on the Election of Members of the DPR, DPD and DPRD has placed the election management institution as an institution with broad authority. However, there are no rules for the passage of institutional control. Thus, the people's political choices can be changed or even steered for certain political interests. This condition leads to a democratic process that is misguided and largely determined by transactional patterns among actors who intended to gain political and financial interests.[5]

The 2019 General Election, which took place on April 17, 2019, had once again made a new history in the transformation of government in Indonesia. Tens of thousands of legislative candidates campaigned for hot seats in the legislative bodies. Many things came into the spotlight and were considered as weaknesses in the election. These weaknesses are both substantive and technical. Ethical issues are not only related to the KPU (Election Commission) as the election organizer. Political parties as election participants also play a major role in maintaining the integrity of the election through their ethical behavior. Political parties are expected not to take any means, including actions, that violate ethics to make their candidate qualified as election participants.[6]

\section{RESEARCH METHOD}

This study aims to find and generate a model and implementation of the ideal concept of legislators' integrity through a low-cost election process. The study employed normative and empirical legal methods. It begins with literature reviews and followed by field investigations, and analysis in order to create an appropriate and working model and implementation of low cost legislative election process.[7]

\section{FINDINGS AND DISCUSSION}

The purpose of law is not only for order and justice but also for transforming and renewing society. Law is also a medium to pass on the society's character and way of thinking so that it can deal with the different aspects of human development in Indonesia. The term government official or public official in Indonesian consists of two words, namely official and Public. The Big Indonesian Dictionary defines pejabat as government employees who occupy important positions (leading elements). The word public is defined as a lot of people (general) [8] 
Public official must be a role model for the community by fulfilling or carrying out their duties in accordance with their oath of office. The position given is a mandate of the people. It is a belief and expectations that cannot be denied. When a public official has taken the oath of office, his/her moral responsibility to the general public cannot be neglected. Public trust in public officials will not be lost so that the public will be quickly invited to participate in the election of public officials. [9]

The practice of money politics in legislative election is a fraud in the administration of election. Deviation or fraud committed by political parties are not the object of this study because it is not considered as a crime. Although this fraud is often called an election crime committed by a political party, this study does not see political party's fraud as a criminal act based on the following reasons.[10]

Norms and sanctions for this violation in the Law number 3 of 1999 on General Elections is not included in the chapter on Criminal Provisions. If this kind of case constitutes an election crime, then it will surely be included in one of the election crimes, together with other election crimes in Articles 72 and 73 of the Law number 3 of 1999. Sanctions that are threatened for political parties that do not report campaign funds are not criminal sanctions. It is administrative sanctions in the form of cessation of funding assistance from the Revenue and Expenditure Budget.[11]

Sanctions that can be imposed on political parties that violate the provisions regarding limits on campaign funds and foreign funds are not criminal sanctions but administrative sanctions (See Articles 17 and 18 of the Law number 2 of 1999). To resolve political party fraud, it must be carried out through a lawsuit, not a prosecution and the prosecutor's office. The use of litigation is only recognized in civil cases, not criminal cases. Based on these reasons, the fraud committed by political parties, even though it is related to general elections cannot be called an election crime, but it is part of election fraud in a broad sense.[12]

They are similar with the criminal acts listed in Article 19 of the Law number 2 of 1999 on Political Parties. The article threatens anyone who contributes to the party, or gives money or goods to others to contribute to the party, accepts money or goods from other people to be donated to the party, or compels any person or institution to make any form of donation to the party, if the contribution exceeds the requirement.[13] The sanctions for these violations are imprisonment for a maximum of 30 days or a fine of a maximum of 100 million rupiahs. This article is clearly a criminal offense because the sanction for this violation is a criminal sanction (imprisonment or fine). It cannot be called an election crime because the prohibited act can be carried out at any time outside the election time. Thus the donation or the contribution may have no correlation with the election.[14]

The articles regulating settlement of election violations in the Law number 7 of 2017 on the Election of Members of the DPR, DPD, and DPRD is completely inadequate in the realization of law enforcement against election crimes. Settlement of election criminal offenses is limited to completion no later than 5 (five) days before the KPU determines the results of the national election, after first report to Bawaslu. The regulation limits the legality of prosecution of election crimes after the deadline. Allegations of holding elections that were uncovered after the ballot were easily declared out of date for legal action.[15]

Law enforcers (the national police) can work to deal with election crimes, without being limited by the Bawaslu reporting procedures with their staff, nor are they constrained by the issue of 'expiration' of election crimes based on clearer, firmer, and specific legal provisions. It is clear that the strengthening of the 'electoral justice system' must be an integral part of the revision process of the Election Organizing Law and the upcoming Election Law for DPR, DPD, and DPRD.[16]

Omission or tolerance of election crimes has a destructive impact not only on the aggrieved parties, but also systematically damages the joints of democratic consolidation. All kinds of democratic pathologies will proliferate if there is no change in election regulations and an increase in the performance of law enforcement that allows electoral crime plotters or actors to remain free to play a role in undermining the integrity of the electoral process.[17] An act that is prohibited by a regulation is accompanied by threats (sanctions) in the form of certain crimes for anyone who violates the prohibition. It can also be said that a criminal act is an act that is prohibited by a rule of law and is punishable by a criminal act, (i.e., a situation or event caused by a person's behavior), while the criminal threat is directed at the person who caused the incident.[18]

The implementation of general elections cannot be separated from various forms of crime and violations. Therefore, it is necessary to have a legal instrument that regulates the forms of crime and violations in the implementation of general election. As for Indonesia, the occurrence of violations in the implementation of the general election is unavoidable. Hitherto, the legal sanctions that have been imposed on them are merely the removal of their names from the nominations and no legal action has been taken regarding this issue.[19]

On the other hand, it seems that law enforcement officers also do not understand the application of material legal rules in the field of criminal acts related to general election. In the legislative election, identity politics is not expected to be used by many candidates for several reasons, including the diverse composition of voters and legislative candidates from internal political parties. The candidates will be careful in using issues in the campaign. In addition, the level of contestation in the upcoming election will also be heavy, both internally and externally.[20]

The current statutory regulations do not provide fines for officials who do not keep their oath of office. Legislation is undeniably a political product that prioritizes political interests. It can be understood that legislators do not include penalties in the oath of office 
because they are the ones most likely to violate them. It is also illegal to refuse to take the oath of office.[21]

\section{CONCLUSION}

The integrity of legislative members is currently influenced by several factors. They include the high cost of politics which evidently has had a significant impact on the legislators' performance. Due to very high political costs, when someone is elected legislative member, she or he may think to recoup the cost. The amount of money spent by legislative candidates can motivate them to commit corruption once they are elected. Currently, the effort that must be done is to cut the high political costs. Thus, elected legislative members can focus to carry out their duties and functions. There is a need of a joint effort among regulators, political parties, and the community to create low-cost legislative elections to realize the integrity of legislative members.

\section{REFERENCES}

[1] R. Danendra, I. G. Ayu, K. Rachmi, and A. K. Jaelani, "Legal Protection of Non Wage Workers Rights After Omnibus Law," Jurisprudentie, vol. 8, no. 13, pp. 85-99, 2021.

[2] L. C. Lintang, Adriano Martufi, and J.W. Ouwerker, "The Alternative Concepts of Blasphemy Law in Indonesia: Legal Comparison with Ireland and Canada," Bestuur, vol. 8, no. 2, pp. 121-128, 2020.

[3] M. Pungky and H. Wijaya, "Legislation Impediments in Reorganising Government Bodies in Indonesia," Bestuur, vol. 9, no. 1, pp. 1-16, 2021.

[4] S. R. Novikasari, D. Q. Ly, and K. Gershaneck, "Taxing Micro, Small and Medium Enterprises in Yogyakarta: Regulation and Compliance," Bestuur, vol. 9, no. 1, 2021.

[5] Saidah Fasihah Binti Che Yussoff and R. Nordin, "Freedom of Expression in Malaysia: Compatibility with the International Human Rights Standard Saidah," Bestuur, vol. 9, no. 1, pp. 44-59, 2021.

[6] U. K. Mishra and A. Negi, "Transgender and the Right to Employment in India: Analysing the Trajectories of Discrimination," Bestuur, vol. 9, no. 1, pp. 34-43, 2021.

[7] H. J. Noor, K. Afkar, H. Glaser, and U. G. Mada, "Application of Sanctions Against State Administrative Officials Failing to Implement Administrative Court Decisions," Bestuur, vol. 9, no. 1, pp. 73-93, 2021.

[8] N. P. Hidayah, "The Implementation of Labor Development Principles According to Job Creation Law as a Reason to Protect Wages Rights," Bestuur, vol. 8, no. 2, pp. 121-128, 2020.

[9] W. B. Putri et al., "Medicolegal Perspective on Physician-Induced Demand Issue," Bestuur, vol. 9, no. 1, pp. 106-124, 2021.

[10] N. Ishak, R. R. Hasibuan, and T. S. Arbani, "Bureaucratic and Political Collaboration Towards a Good Governance System," Bestuur, vol. 8, no. 1, p. 19, 2020.
[11] N. Zubaidi, R. G. Pratama, and S. Al-Fatih, "Legal Perspective on Effectiveness of Pre-Work Cards for Indonesian People," Bestuur, vol. 8, no. 1, p. 9, 2020.

[12] L. Karjoko et al., "PATENT POLICY ON THE PHARMACEUTICAL SECTOR IN INDONESIA," vol. 23, no. 5, pp. 1-13, 2020.

[13] E. Sukmoro, A. Sulistiyono, and L. Karjoko, "The politic of law of PT. Kereta api Indonesia (persero) track access charge policy based on justice," Int. J. Adv. Sci. Technol., vol. 28, no. 20, pp. 353-361, 2019.

[14] Prasetio et al., "Problems of democratic and dignified election in indonesian simultaneously electoral era," Int. J. Criminol. Sociol., vol. 9, pp. 1701-1708, 2020.

[15] I. G. A. K. R. Handayani, L. Karjoko, and A. K. Jaelani, "Model Pelaksanaan Putusan Mahkamah Konstitusi yang Eksekutabilitas Dalam Pengujian Peraturan Perundang-Undangan di Indonesia," Bestuur, vol. 7, no. 1, pp. 36-46, 2019.

[16] S. D. Baranyanan, I. G. A. K. R. Handayani, and Isharyanto, "Political law of local government to resolve disputes adat law in Kei Island," Int. J. Adv. Sci. Technol., vol. 28, no. 20, pp. 494-499, 2019.

[17] E. T. Gomez, "Resisting the Fall: The Single Dominant Party, Policies and Elections in Malaysia," J. Contemp. Asia, vol. 46, no. 4, pp. 570590, 2016.

[18] F. Khairo et al., "Urgensi Contempt of Court Dalam Meningkatkan Wibawa," vol. 4, pp. 597-604, 2017.

[19] L. Karjoko, I. G. A. K. R. Handayani, A. S. Sudarwanto, D. W. Winarno, A. K. Jaelani, and W. N. Hanum, "THE CONSEQUENCE OF THE DECISION OF THE CONSTITUTIONAL COURT IN FORESTRY ON THE RECOGNITION OF TRADITIONAL FORESTS IN," J. Leg. Ethical Regul. Issues, vol. 24, no. 5, pp. 1-8, 2021.

[20] I. Iswantoro, "Strategy and Management of Dispute Resolution , Land Conflicts at the Land Office of Sleman Regency," J. Hum. Rights, Cult. Leg. Syst., vol. 1, no. 1, pp. 1-17, 2021.

[21] F. U. Najicha, "Oil and Natural Gas Management Policy in Realizing Equal Energy in Indonesia," $J$. Hum. Rights, Cult. Leg. Syst., vol. 1, no. 2, pp. 7179, 2021. 